\title{
REVIEW
}

\section{Endoscopic Procedures In Patients Taking Novel Oral Anticoagulants}

\author{
Raluca Anica IONESCU ${ }^{1}$, Andreea GHIDERSA', Roxana SADAGURSCHI', Lucian NEGREANU, \\ Ruxandra BABIUC
}

\begin{abstract}
The use of direct oral anticoagulants (DOAC) for the treatment of atrial fibrillation and prevention of strokes is encouraged by their superior properties compared to vitamin $\mathrm{K}$ antagonists: predictable anticoagulant effect, greater patient compliance, few drug interactions, low risk of intracranial hemorrhages. Although practicing gastroenterologists may never prescribe a DOAC, they are likely to encounter DOAC-related GI adverse events (gastrointestinal bleeding), and they will need to manage DOACs around the time of endoscopy. The present paper aims to present the management possibilities of the patient treated with DOAC undergoing endoscopy, most studies performed so far focusing on the risk of spontaneous bleeding in this category of subjects. The current guidelines provided by the British Society of Gastroenterology and the European Society of Gastrointestinal Endoscopy orientate us, but endoscopic maneuvers should be preceded by a detailed analysis of the risks of secondary bleeding and thrombosis associated with DOAC users.
\end{abstract}

Keywords: novel oral anticoagulant, gastrointestinal bleeding, time of endoscopy.

\section{Rezumat}

Utilizarea anticoagulantelor orale directe (DOAC) pentru tratamentul fibrilației atriale și prevenția accidentelor vasculare cerebrale este încurajată de proprietățile superioare ale acestora, comparativ cu antagoniștii de vitamina K: efect anticoagulant predictibil, complianța mai mare a pacientului la tratament, interacțiuni medicamentoase puține, risc scăzut al hemoragiilor intracraniene. Deși gastroenterologii nu prescriu în practica curentă NOAC, se pot confrunta cu reacțiile adverse ale acestora (sângerare gastrointestinală) și în consecință vor trebui să gestioneze administrarea lor în momentul endoscopiei. Lucrarea de față are ca scop prezentarea posibilităților de management al pacientului aflat sub tratament cu DOAC și supus unor gesturi endoscopice, cele mai multe studii efectuate până în prezent axându-se pe riscul hemoragiilor spontane la această categorie de subiecți. Ghidurile actuale oferite de Societatea Britanică de Gastroenterologie și Societatea Europeană de Endoscopie Gastrointestinală ne orientează, însă manevrele endoscopice ar trebui precedate de o analiză detaliată a riscurilor de hemoragie secundară, respectiv tromboza, asociate pacienților cu DOAC.

Cuvinte cheie: anticoagulant oral nou, sângerare gastrointestinală, endoscopie.

'Department of Gastroenterology, Emergency University Hospital, Bucharest, Romania
Corresponding author:

Ruxandra BABIUC, Department of Gastroenterology, Emergency University Hospital, Bucharest, Romania.

E-mail: doina_babiuc@yahoo.com 
New oral anticoagulants, also known as direct oral anticoagulants (NOAC/DOAC) are drugs used in patients with non-valvular atrial fibrillation to prevent stroke. They have some advantages compared to vitamin K inhibitors: a predictable anticoagulant effect, eliminating the need to monitor coagulation parameters, fewer drug interactions and a substantially lower risk of intracranial bleeding. However, DOAC therapy carry a higher risk of digestive bleeding compared to warfarin ${ }^{1}$. Numerous studies have been carried out on the risk of spontaneous digestive bleeding in patients treated with DOAC or vitamin $\mathrm{K}$ antagonists. Apixaban is associated with the lowest risk of digestive bleeding, rivaroxaban being placed at the end of the ranking ${ }^{2-4}$.

There is an increasingly number of studies related to the risk of hemorrhage secondary to an endoscopic gesture in patients treated with DOAC, respectively to the thrombotic risk that may occur by short-term anticoagulant cessation in order to perform an urgent or an elective endoscopic maneuver. Any endoscopic intervention carries an intrinsic risk of hemorrhagic complication and bleeding is considered clinically significant if serum hemoglobin decreases by at least $2 \mathrm{~g} / \mathrm{dL}$, if requires blood transfusion and symptoms like melena or hematemesis occur.

For the anticoagulated patients, this risk is higher, depending on the endoscopic maneuver practiced, as well as the type of DOAC. Simple diagnostic procedures like gastroscopy, colonoscopy, or sigmoidoscopy with biopsy have a low risk of intra-procedural bleeding. Current guidelines recommend skipping the DOAC dose in the morning of the procedure ${ }^{5}$. Probably a simple biopsy in these patients is safe, but more data are needed to confirm ${ }^{6}$ and herefore, it is probably safer to comply with the recommendations.

High-risk procedures including polypectomy, endoscopic retrograde cholangio-pancreatography (ERCP) with sphincterotomy, ampullectomy, submucosal endoscopic dissection (ESD), endoscopic mucosal resection (EMR), stricture dilation, band ligation or gastric varices glue therapy, endoscopic ultrasound-guided fine-needle aspiration biopsy (EUS with FNA), percutaneous endoscopic gastrostomy (PEG), requires more careful handling of DOAC administration.

The recommendation of the British Society of Gastroenterology and the European Society of Gastrointestinal Endoscopy is to administer the last dose of DOAC at least 48 hours before a high-risk endoscopic procedure; for patients treated with dabigatran, the measurement of the glomerular filtration rate is mandatory to decide the optimal time to discontinue DOAC (at RFG between 30 and $50 \mathrm{~mL} / \mathrm{min} / 1.73 \mathrm{~m} 2$ cessation of treatment with dabigatran is done 72 hours before a high-risk endoscopic intervention to reduce the risk of secondary bleeding) $)^{5}$. Switching to low-molecular-weight heparin therapy (LMWH) is not necessary, considering the rapid action of DOAC. It has been shown that in patients treated with rivaroxaban, switching to LMWH has led to a much higher frequency of gastrointestinal bleeding (up to 6.5\%), but thrombotic risk analysis is mandatory, especially in patients at high cardiovascular risk ${ }^{7,8}$.

Post-polypectomy bleeding (PPB) is a common but sometimes can be massive and a life-threatening complication. It can be immediate (intraprocedural), which is usually self-limited and could be controlled during endoscopy, or delayed, much more worrying, bearing in mind that the patient is already discharged. The associated risk factors are represented by the size of the polyp $(>1 \mathrm{~cm})$, the pedunculate appearance, the endoscopic technique used, the advanced age ( $>65$ years), the chronical renal or cardiovascular diseases, the use of anticoagulant, anti-inflammatory treatment (NSAID), inadequate preparation for colonoscopy ${ }^{9,10}$. With regard to DOAC, the risk of PPB is not well known. The frequency of polypectomy complications was compared in a group of 218 anticoagulated patients, of whom 73 were DOAC users and 218 patients without anticoagulant treatment ${ }^{11}$; a similar bleeding rate between DOAC and warfarin was observed, but much higher compared to subjects who did not receive anticoagulant treatment ( $13.7 \%$ vs $13.7 \%$ vs. $0.9 \%, \mathrm{P}<0.001)$.

Similarly, newer data from the literature (2019) show a frequency of $0.6 \%$ of gastrointestinal bleeding within 30 days of polypectomy among patients treated with DOAC ( $\mathrm{n}=1.950)$, and this frequency was not much higher than in the control group $(0.2 \%)^{12}$. The study included 1590 patients under DOAC, 3471 patients treated with warfarin and 599.983 patients in the control group. However, a higher frequency of bleeding was observed in the group of patients treated with warfarin compared to the control group (1.2\%), as well as thromboembolic complications. Recently a Japanese study reported the frequency of gastrointestinal bleeding within 30 days of endoscopic gesture in patients under DOAC, most of the lesions analyzed being those at the colonic level $(82.1 \%)^{13} 389$ and 383 patients were receiving direct oral anticoagulants (DOACs. The study 
included 772 subjects, of whom 389 were in treatment with DOAC. The average bleeding rate was $9.5 \%$, the apixaban and edoxaban being the most incriminated (the frequency of bleeding of about 13\%); contrary to the data from specific literature, rivaroxaban presented the best safety profile (bleeding rate of $6.4 \%$ ). The highest risk techniques were represented by ESD and EMR (bleeding rate of $16 \%$ and $10.9 \%$, respectively). However, the researchers noted a lower need for endoscopic hemostasis in patients treated with DOAC compared to patients treated with warfarin, which demonstrates a much better safety profile of DOAC.

Endoscopic mucosal resection (EMR) presents a general risk of intraprocedural and delayed bleeding between $3.7 \%-11.3 \%$ and, respectively, $0.6 \%-6.2 \%{ }^{5}$. Risk factors associated with secondary hemorrhage EMR include proximal location of lesion, dimensions, endoscopic pattern, resection technique, anticoagulant/anti-inflammatory treatment (NSAID) ${ }^{14,15}$. Post-EMR delayed bleeding prediction scores (GSEED-RE2) were proposed, based on variables such as lesion size, proximal location, associated comorbidities and antithrombotic treatment, which could guide endoscopic therapies and be a useful tool in clinical trials to evaluate bleeding prevention strategies after broad $\mathrm{EMR}^{16}$. To reduce the risk of post EMR hemorrhages, prophylactic measures, such as the use of hemoclips or of Purastat, a hemostatic gel, may be useful. A retrospective study demonstrates much lower bleeding rates for lesions larger than $2 \mathrm{~cm}$ resected by EMR technique when hemoclips were used to close the defect $(1.8 \%$ vs. $9.7 \%)^{17}$. However, the authors encourage prospective studies to address this topic for most reliable results and encourage a careful hemostasis during the procedure. In contrast to these data, other studies question the usefulness of these prophylactic measures, especially in the case of small lesions bearing in mind the associated higher costs ${ }^{18,19}$. A multicenter study published in 2019 included a total of 2,062 subjects undergoing EMR for colonic lesions and analyzed the incidence of post-interventional bleeding in patients on antithrombotic treatment. The frequency of hemorrhage was highest in the DOAC users, despite the use of endoscopic clips as a hemostatic method (7.9\% vs. $2.9 \%$ for warfarin, $3.2 \%$ for antiplatelets, $0.6 \%$ in the control group), without significant differences between DOAC subtypes. No thromboembolic events were reported in this category of patients. In view of these results, the procedure is considered of high risk and the recommendations of European guidelines should be followed.
Endoscopic submucous dissection (ESD) is a more recent and complex technique, with increasing worldwide popularity and very good results in early gastric cancer treatment. The hemorrhagic risk is increased by the size of the resected specimen (fragments over 35 $\mathrm{mm}$ being considered at risk) according to a recent $\mathrm{Ko}^{-}$ rean study, independent of the presence of anticoagulant treatment ${ }^{20}$. Post-endoscopic haemorrhage was less common in subjects treated with DOAC than in those treated with warfarin. Following the recommendations of the current guidelines, the study found 3 cases of post procedural bleeding, respectively one case of thrombosis (myocardial infarction) occurring 3 weeks after endoscopy. Endoscopic control was carried out one day after the ESD procedure, suggesting the need for further studies to clarify the necessity of an endoscopic second look in patients receiving DOAC when performing ESD. In addition, older data in the literature regarding this subject are contradictory, the results being limited to the category of subjects without DOAC treatment ${ }^{21-23}$. Prevention of post-ESD bleeding is very important; the use of polyglycolic acid, fibrin adhesive, endoscopic coagulation, endoscopic clips being effective in different studies ${ }^{24-26}$.

Endoscopic procedures such as balloon dilation or gastrointestinal stenting may be associated with some risk of bleeding.

Endoscopic dilation is used for the treatment of benign strictures of various causes (peptic, post caustic, post surgical, post radiotherapy); the procedure is a safe one from the perspective of occurrence of intra-procedural hemorrhages ${ }^{27}$. The technique was also applied for the treatment of post ESD stenosis after superficial esophageal cancer with an insignificant rate of secondary hemorrhage being $(0.8 \%)^{28}$. Endoscopic dilation of strictures secondary in inflammatory bowel diseases is also a safe maneuver, the frequency of bleeding being estimated at $1 \%{ }^{29}$.

Endoscopic stenting remains an important tool in the management of malignant diseases of the digestive tract, bleeding rates ranging between $2 \%$ and $13.4 \%$ in the case of esophageal lesions, up to $5 \%$ for gastro-duodenal and colonic lesions stented ${ }^{30-33}$. Unfortunately, there are currently very few data related to the hemorrhagic complications of this endoscopic technique in the anticoagulated patient.

Endoscopic retrograde cholangiopancreatography (ERCP) with sphincterotomy is associated with a bleeding risk of up to $2 \%{ }^{34}$. This risk can be amplified by 
factors such as male sex, advanced age ( $>80$ years), low number of thrombocytes $(<100.000 / \mathrm{uL})$, anticoagulant use $^{35,36}$. With regard to DOAC, they have been proven to have a lower risk of endoscopic bleeding when compared to vitamin $\mathrm{K}$ antagonists; the possibility of thromboembolic events was analyzed, the results being encouraging for DOAC users ${ }^{37}$. Masuda et all demonstrated that stopping the anticoagulant for at least 48 hours before ERCP is associated with a lower bleeding rate $(5.6 \%$ vs. $20.8 \%$ in case of interrupting DOAC for less than 2 days prior to surgery); none of the study participants showed thromboembolic events ${ }^{36}$. Considering that the study included a small number of patients treated with DOAC $(n=42)$, although the results are encouraging in the group of subjects who have stopped taking anticoagulants for at least 48 hours, the thrombotic risk should be well weighed for an effective patient management.

Endoscopic ampullectomy is a minimally invasive method of treating superficial lesions of the ampulla Vater. With a careful patient selection and assessment of lesions, it is a safe and effective therapeutic procedure that can avoid the need for potentially major surgery. The associated risk of bleeding was approximately $8.5 \%{ }^{38}$. Currently, there are no data in the literature to guide us the situation of anticoagulated patients undergoing endoscopic ampullectomy so it is very important to analyze the individual hemorrhagic risk ${ }^{5}$.

Percutaneous endoscopic gastrostomy (PEG) can be complicated by an abdominal wall hemorrhage and hematoma or other bleeding complications with a recent prospective study estimating bleeding incidence at $1 \% 39$. The incidence of secondary bleeding after PEG placement was estimated at $3.3 \%$ in a report published in 2011; the highest bleeding rates were seen in subjects treated with low-molecular-weight heparin (LMWH) and those with more than two antithrombotic drugs (7.9\%, 6.3\%); low bleeding rates were found in patients treated with clopidogrel $(2.1 \%)^{40}$. Probably stopping DOAC with at least $48 \mathrm{~h}$ before procedure and bridge with low molecular weight heparin in high risk of thrombosis patients is advisable.

The treatment of choice for esophageal varices bleeding is endoscopic band ligation (EBL); the technique is also used for prophylactic purposes. Data on anticoagulant patients with DOAC who have undergone $\mathrm{EBL}$ are missing, but, regarding the other categories of anticoagulants, the literature offers some directions for a safer management. In 2008 a retrospective analy- sis of anticoagulated patients who underwent EBL for primary/secondary prevention of hemorrhage was carried out. Five out of 215 subjects required permanent anticoagulation, being diagnosed with cardiac cirrhosis, Budd Chiari syndrome, polycytemia vera and portal vein thrombosis, primitive sclerosing colangitis and cryptogenic cirrhosis. Anticoagulant treatment was maintained before and after EBL, with the preservation of INR values within therapeutic limits, and none of the patients developed gastrointestinal bleeding either immediate or within 2 weeks of endoscopic interventi$\mathrm{on}^{41}$. These results support the possibility of practicing EBL for primary/secondary prophylaxis in patients treated with oral anticoagulants. However, given the small number of subjects who have experienced this procedure, additional data are needed for an optimized management. Same rule of $48 \mathrm{~h}$ stop of DOAC and transition to LMWH prior to endoscopic procedure in patients with high risk of thrombosis ${ }^{5,42}$.

Endoscopic ultrasound-guided fine-needle aspiration biopsy (EUS-FNA) has revolutionized the ability to diagnose and staging tumors of the gastrointestinal tract and neighboring organs, especially the pancreas. Although the procedure includes tissue puncture, the reported incidence of bleeding is low. A systematic review that included 51 articles with a total of 10,941 patients undergoing EUS-FNA, showed bleeding in $0.17 \%$ of procedures, most appearing after performing this procedure on pancreatic lesions ${ }^{43}$. Data on patients treated with DOAC are missing, but the procedure is considered safe for patients on antiaggregant / anti-inflammatory therapy (NSAIDs) treatment ${ }^{43}$.

As the population ages and the incidence of chronic diseases increases, the need for anticoagulant treatment is increasing; the widespread use of DOAC has increased in recent years. At present, the existing guidelines orientate us, but additional research should be encouraged in order to achieve an optimal risk-benefit ratio for our patients. A decision should be taken in every case after carefully balancing bleeding and thrombotic risks.

\section{Compliance with ethics requirements:}

The authors declare no conflict of interest regarding this article. The authors declare that all the procedures and experiments of this study respect the ethical standards in the Helsinki Declaration of 1975, as revised in 2008(5), as well as the national law. Informed consent was obtained from all the patients included in the study. 


\section{References}

1. Ruff CT, Giugliano RP, Braunwald E, et al. Comparison of the effi cacy and safety of new oral anticoagulants with warfarin in patients with atrial fi brillation: a meta-analysis of randomised trials. Published online 2014:955-962. doi:10.1016/S01406736(13)62343-0

2. Souverein PC, Ham HA Van Den, Martín E, et al. Comparing risk of major bleeding between users of different oral anticoagulants in patients with nonvalvular atrial fibrillation. 2021;(February 2020):988-1000. doi:10.1111/bcp.14450

3. Study P, Abraham NS, Noseworthy PA, Yao X, Sangaralingham LR, Shah ND. Gastrointestinal Safety of Direct Oral Anticoagulants: A Large Population-Based Study. Gastroenterology. 2017;152(5):1014-1022.e1. doi:10.1053/j.gastro.2016.12.018

4. Cheung K, Leung WK. Gastrointestinal bleeding in patients on novel oral anticoagulants: Risk, prevention and management. 2017;23(11):1954-1963. doi:10.3748/wjg.v23.i11.1954

5. Veitch AM, Vanbiervliet G, Gershlick AH, et al. Endoscopy in patients on antiplatelet or anticoagulant therapy, including direct oral anticoagulants: British Society of Gastroenterology (BSG) and European Society of Gastrointestinal Endoscopy (ESGE) guidelines. Published online 2016:374-389. doi:10.1136/gutjnl-2015-311110

6. Submitted, not presented: general endoscopy 2789. 2018;2018:2790. doi:10.1038/ajg.2018.325

7. Douketis JD, Healey JS, Brueckmann M, et al. Perioperative bridging anticoagulation during dabigatran or warfarin interruption among patients with an elective surgery or procedure Substudy of the RE-LY trial. Published online 2015:1-9.

8. Ebertz F, Beyer-westendorf J, Gelbricht V, et al. Peri-interventional management of novel oral anticoagulants in daily care : results from the prospective Dresden NOAC registry. Published online 2014. doi:10.1093/eurheartj/eht557

9. Liu C, Wu R, Sun X, Tao C, Liu Z. Risk factors for delayed hemorrhage after colonoscopic postpolypectomy: Polyp size and operative modality. Published online 2018:61-64. doi:10.1002/ jgh3.12106

10. Kim HS, Kim TI, Kim WH, et al. Risk Factors for Immediate Postpolypectomy Bleeding of the Colon : A Multicenter Study. Published online 2006:1333-1341. doi:10.1111/j.1572-0241.2006.00638.x

11. Maida M, Sferrazza S, Maida C, Morreale GC, Vitello A, Longo G, Garofalo V SE. Management of antiplatelet or anticoagulant therapy in endoscopy: A review of literature. World $\mathrm{J}$ Gastrointest Endosc. 2020;12(6)(172-192).

12. Yu JX, Oliver M, Lin J, et al. Patients Prescribed Direct-Acting Oral Anticoagulants Have Low Risk of Postpolypectomy Complications. Clin Gastroenterol Hepatol. 2019;17(10):2000-2007.e3. doi:10.1016/j.cgh.2018.11.051

13. Kubo K, Kato M, Mabe K, et al. Risk Factors for Delayed Bleeding after Therapeutic Gastrointestinal Endoscopy in Patients Receiving Oral Anticoagulants: A Multicenter Retrospective Study. 2019;8512. doi:10.1159/000502952

14. Shiba M, Higuchi $K$, Kadouchi $K$, et al. Risk factors for bleeding after endoscopic mucosal resection. 2005;11(46):7335-7339.

15. Metz AJ, Bourke MJ, Moss A, et al. Factors that predict bleeding following endoscopic mucosal resection of large colonic lesions. 2011; (August 2006):506-511

16. Albéniz E, Gimeno-garcía AZ, Fraile M, Álvarez A, Gargallo CJ, Pellisé M. Clinical validation of risk-scoring systems to predict risk of delayed bleeding after endoscopic mucosal resection of large colorectal lesions. Gastrointest Endosc. doi:10.1016/j. gie.2019.10.013
17. Liaquat H, Rohn E, Rex DK. Prophylactic clip closure reduced the risk of delayed postpolypectomy hemorrhage : experience in 277 clipped large sessile or flat colorectal lesions and 247 control lesions. YMGE. 2013;77(3):401-407. doi:10.1016/j.gie.2012.10.024

18. Feagins LA, Nguyen AD. The Prophylactic Placement of Hemoclips to Prevent Delayed Post-polypectomy Bleeding: An Unnecessary Practice? A Case Control Study. Published online 2014. doi:10.1007/s10620-014-3055-0

19. Chen C, Kuo C, Chiu C, et al. The effect of prophylactic hemoclip placement and risk factors of delayed post- polypectomy bleeding in polyps sized 6 to 20 millimeters : a propensity score matching analysis. Published online 2020:1-9.

20. Toya $Y$, Endo M, Oizumi T, Akasaka R, Yanai S, Kawasaki K. Risk Factors for Post - gastric Endoscopic Submucosal Dissection Bleeding with a Special Emphasis on Anticoagulant Therapy. Dig Dis Sci. 2019;(0123456789). doi:10.1007/s10620-019-05776-3

21. Mochizuki S, Uedo N, Oda I, et al. Scheduled second-look endoscopy is not recommended after endoscopic submucosal dissection for gastric neoplasms ( the SAFE trial ): a multicentre prospective randomised controlled. Published online 2014:1-9. doi:10.1136/gutjnl-2014-307552

22. Kim S, Choi C, Kang D, et al. Second-look endoscopy and factors associated with delayed bleeding after endoscopic submucosal dissection. 2016;8(3):173-179. doi:10.4253/wjge.v8.i3.173

23. Park CH, Park JC, Lee H, Shin SK, Lee SK, Lee YC. Second-Look Endoscopy after Gastric Endoscopic Submucosal Dissection for Reducing Delayed Postoperative Bleeding. 2015;9(1):43-51.

24. Tsuji Y, Fujishiro M, Kodashima S. Polyglycolic acid sheets and $\mathrm{fi}$ brin glue decrease the risk of bleeding after endoscopic submucosal dissection of gastric neoplasms ( with video ). Gastrointest Endosc. 2015;81(4):906-912. doi:10.1016/j.gie.2014.08.028

25. Azumi M, Takeuchi M, Koseki Y, Kumagai M, Kobayashi Y, Takatsuna M. The search, coagulation, and clipping ( SCC ) method prevents delayed bleeding after gastric endoscopic submucosal dissection. Gastric Cancer. 2019;22(3):567-575. doi:10.1007/ s10120-018-0878-y

26. Kawata N, Ono H, Takizawa K, Kakushima N, Tanaka M, Igarashi K. Efficacy of polyglycolic acid sheets and fibrin glue for prevention of bleeding after gastric endoscopic submucosal dissection in patients under continued antithrombotic agents. Gastric Cancer. 2018;(0123456789). doi:10.1007/s10120-018-0791-4

27. Ph D, Ramires RP, Zamin I, Cassal AP. Endoscopic Dilation of Benign Esophageal Strictures: Report on 1043 Procedures. 1999;94(6)

28. Kishida Y, Kakushima N, Kawata N. Complications of endoscopic dilation for esophageal stenosis after endoscopic submucosal dissection of superficial esophageal cancer. Published online 2014. doi:10.1007/s00464-014-4028-2

29. Gustavsson A, Magnuson A, Blomberg B, Andersson M, Halfvarson J, Tysk C. Alimentary Pharmacology and Therapeutics Endoscopic dilation is an ef $\mathrm{fi}$ cacious and safe treatment of intestinal strictures in Crohn ' s disease. 2012;(March). doi:10.1111/j.13652036.2012.05146.x

30. Essrani R, Shah H, Shah S, Macfarlan J. Complications Related to Esophageal Stent (Boston Scientific Wallflex vs . Merit Medical Endotek ) Use in Benign and Malignant Conditions. 2020;12(3). doi:10.7759/cureus.7380

31. Kujawski K, Ef MS, G JR. The evaluation of esophageal stenting complications in palliative treatment of dysphagia related to esophageal cancer. 2012;18(5):323-329. 
32. Growth Charts - WHO Child Growth Standards. Accessed November 16, 2018. https://www.cdc.gov/growthcharts/who_charts.ht-

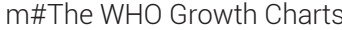

33. Tonolini M, Bareggi E, Salerno R. Endoscopic stenting of malignant, benign and iatrogenic colorectal disorders : a primer for radiologists. Published online 2019:1-14.

34. MARTIN L. FREEMAN, M.D., DOUGLAS B. NELSON, M.D., STUART SHERMAN, M.D., GREGORY B. HABER MD, MARY E. HERMAN, R.N., PAUL J. DORSHER, M.D., JOSEPH P. MOORE, M.D., M. BRIAN FENNERTY MD, MICHAEL E. RYAN, M.D., MICHAEL J. SHAW, M.D. JEFFREY D. LANDE, M.S., AND ALFRED M. PHELEY P. COMPLICATIONS OF ENDOSCOPIC BILIARY SPHINCTEROTOMY. N Engl J Med. 1996;335(13):909-918

35. Muro S, Toyokawa T, Nishimura M, Yunoki N, Okada H. Comparison of anticoagulants and risk factors for bleeding following endoscopic sphincterotomy among anticoagulant users: Results from a large multicenter retrospective study. Published online 2019:1-6. doi:10.1111/jgh.14764

36. Masuda S. Direct Oral Anticoagulants Increase Bleeding Risk After Endoscopic Sphincterotomy : A Retrospective Study. :1-18.

37. Nagata $N$, Yasunaga $H$, Matsui $H$, et al. Therapeutic endoscopy-related $\mathrm{Gl}$ bleeding and thromboembolic events in patients using warfarin or direct oral anticoagulants : results from a large nationwide database analysis. Published online 2018:1805-1812 doi:10.1136/gutjnl-2017-313999
38. Espinel J, Pinedo E, Ojeda V, Guerra-del-río M. Endoscopic ampullectomy : a technical review. 2016;108:271-278.

39. Anderloni A, Di M, Barzaghi F, et al. Complications and early mortality in percutaneous endoscopic gastrostomy placement in lombardy : A multicenter prospective cohort study. Dig Liver Dis. 2019;51(10):1380-1387. doi:10.1016/j.dld.2019.03.024

40. Bonham AJ, Clarkston WK. Risk of Bleeding After Percutaneous Endoscopic Gastrostomy ( PEG ). Published online 2012:973-980. doi:10.1007/s10620-011-1965-7

41. Bajaj JS, Franco J. Endoscopic Band Ligation of Esophageal Varices in Patients on Anticoagulation Management of Anticoagulation Around. 2008;42(7):782-785

42. Schepis F, Id O, Articles O, Editor H, Bureau C. No Title. :0-1. doi:10.1111/liv.13728

43. Wang K, Ben Q, Jin Z, Du Y, Zou D, Liao Z. Assessment of morbidity and mortality associated with EUS-guided FNA : a systematic review. 2011;73(2):283-290. doi:10.1016/j.gie.2010.10.045 